\title{
To barn i Kristin Lavransdatters kloster
}

\author{
Oslo er blitt kalt «Nordens Pompeii» - ingen andre steder i Skandinavia finnes det en så stor samling av ruiner \\ og levninger etter middelalderbygninger. Mye av dette ble avdekket i forbindelse med utbyggingen av jern- \\ banen. Nonneseter kloster er imidlertid sparsomt belyst arkeologisk. Vi vet at det var meget rikt, det eide 272 \\ gårder. Kanskje vil man kunne finne rester under dagens bebyggelse? Litterært gir arkeologdatteren Sigrid \\ Undset oss et bilde av klosteret og Oslo når hun lar sin Kristin få et opphold der. Klosterkirken ble revet i 1616.
}

Jacob M. Klafstad

jklaf@broadpark.no

Benediktinerordenens kvinnekloster i Oslo, Nonneseter, opprettet før 1161 og nedlagt i 1547, var ett av fire klostre i MiddelalderOslo. Klosteret lå litt utenfor byen, der dagen Schweigaards gate og Grønlandsleiret krysser hverandre (1). På slutten av 1800-tallet ble to leiegårder oppført på klosteranleggets grunn etter at stein fra murene var blitt brukt til oppføring av byens nye rådhus og til fundamentering i Grønlandsleiret $(1,2)$. Mange gamle leiegårder i Gamlebyen dekker over store deler av bebyggelsen fra middelalderen. En del av denne bebyggelsen er langt på vei kartlagt og inntegnet etter historiske opplysninger og med støtte i arkeologisk arbeid.

Står man i dagens travle gatekryss, kreves det nok en uvanlig velutviklet forestillingsevne å se for seg et praktfullt klosteranlegg og kirke, Nonnebroen og Klosterbekken. I denne situasjonen kommer vår store forfatterinne Sigrid Undset (1882-1949) oss til unnsetning. I sin trilogi om Kristin Lavransdatter fargesetter hun livet også i gamle Oslo på sterkt engasjerende vis. I 1920-årene fulgte hun selv utgravningene av Middelalder-Oslo på nært hold og plasserte Nonneseter riktig inntil dagens gatekryss Schweigaards gate/Grønlandsleiret (1)

\section{To barn i klosteret}

Under anlegging av Schweigaards gate i 1879 ble det utført en begrenset arkeologisk undersøkelse ved grensene til det middelalderske klosteranlegget. Skjelettmateriale herfra ble brakt til det daværende Anatomisk institutt i Universitetets midtbygning. Materialet oppbevares nå i Anatomisk avdeling i Domus Medica i universitetets bygninger på Gaustad.

Forfatteren har tidligere foretatt undersøkelser, også med røntgenteknikk, av kraniemateriale fra middelalderens Oslo (3). Av dette er det tidligere undersøkt fire kranier fra Nonneseter kloster. Et av disse er omtalt $i$ en tidligere artikkel (4). To av de undersøkte har vært barn som har vært begravet på Nonneseter klosters kirkegård. Det foreligger ikke annet skjelettmateriale som kan identifisere dem. Kjønnsbestemmelse kan ikke foretas med pålitelighet hos barn i lav alder. Aldersbestemmelse kan imidlertid utføres med stor sikkerhet ut fra odontologisk undersøkelse, ved direkte inspeksjon og med støtte i røntgenundersøkelse. Det foreligger hos begge blandingstannsett, og alderen kan med stor sikkerhet fastsettes til 8-9 år (fig 1, fig 2).

\section{Barn i klostre}

Fra lang tid tilbake har det vært kjent over hele Europa at foreldre har overlatt oppfostringen av barn til andre eller på annen måte har forlatt sine barn. Hovedkildene for den europeiske tradisjonen er leveregler skrevet av munker og nonner i tidlig middelalder. I sagaene får vi inntrykk av at svært mange barn vokste opp hos andre enn sine biologiske foreldre.

I størstedelen av Europa var det en vanlig tradisjon i middelalderen å gi barn til klostre, mens det i Norge og på Island var vanlig å overlate dem til fosterforeldre. Rike adelsfamilier sendte døtre i kloster for at de skulle leve et trygt liv der. Samtidig ble klostrene tilført økonomiske midler og gjengjeldte med å gi undervisning i latin, kirkelære, musikk og sykepleie. Kjente eksempler er Katharina von Bora (1499-1552), Martin Luthers hustru, og Hildegard von Bingen (1098-1179), som åtte år gammel ble opptatt i Bingen kloster (5).

\section{Klosterkirkegården}

At «våre» to barn var begravet på klosterkirkegården, kan fortelle om varig eller midlertidig tilhørighet i klosteret. En annen orden, Augustinerordenen, hadde i sin kirkegård en avdeling for legfolk, der utenforstå-

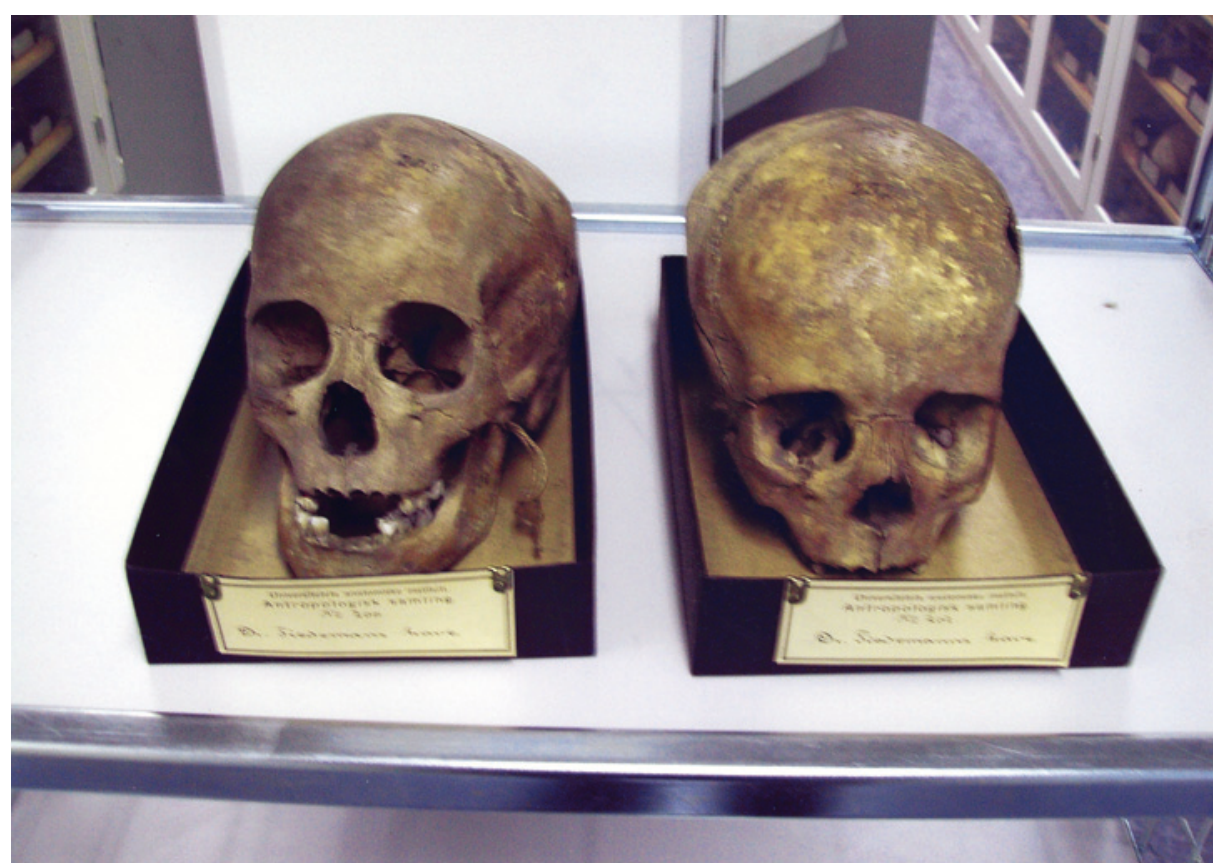

Figur 1 De aktuelle to barnas kranier og kalvarier fotografert i Anatomisk avdeling ved Universitetet i Oslo. Det bemerkes bortfall av de permanente incisiver post mortem. Alderen kan fastsettes å være den samme, 8-9 år, for begge 


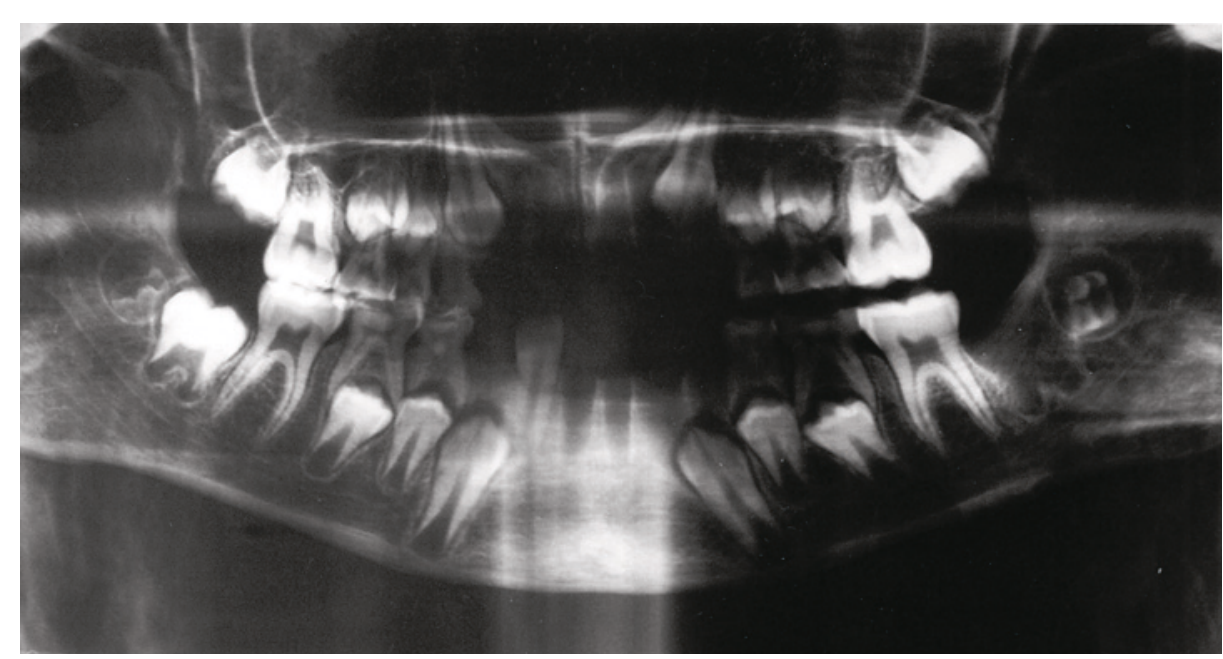

Figur 2 Røntgenogram lortopantogram) av det ene barnet viser blandingstannsett svarende til en alder på 8-9 år. Bemerk alle seksårsmolarer i fullt frembrudd og okklusjon. Anleggene til øvrige permanente tenner er «underveis» og riktig i tid. Permanente incisiver er tapt

ende kunne kjøpe seg et gravsted, og også en fremmedavdeling, der midlertidige pasienter fra for eksempel et fattighospital utenfor klostermurene kunne få gravsted dersom de døde under oppholdet.

Klosterets fastboende arbeidsstab og livsvarige pensjonærer, donati, hadde også rett til å bli begravet på klosterkirkegården (6). Det er ikke urimelig å anta at en liknende organisering har vært praktisert ved vårt hjemlige Nonneseter kloster.

\section{Diskusjon}

Ut fra norsk tradisjon virker det ikke sannsynlig at «våre» to barn er gitt til klosteret for å bli oppfostret der (5). Det kan tenkes flere andre forklaringer, kanskje først og fremst at barna er brakt til klosteret i en nødssituasjon av mor eller andre. «Innleve- ring» av spedbarn til klostre i slike situasjoner har forekommet til alle tider. Barna kan også senere i livet vært brakt til klosteret $\mathrm{i}$ forbindelse med sykdom og avgått ved døden der.

Det kan heller ikke utelukkes at de er født i klosteret. Nonneseter huset jo også en fastboende arbeidsstab med familier, der familieforøkelse sikkert forekom. I sitt omfattende arbeid om Æbelholt kloster har Møller-Christensen undersøkt 104 kvinneskjeletter, hvorav 50 ble ansett å være i befruktningsdyktig alder (6). Av disse fantes fem skjeletter som inneholdt fostre. I vårt tilfelle har vi et brev fra 1352 som forteller om en «nødssituasjon»: Enken Elin Tordsdatter Agaten i Oslo skrev da i sitt testament at hun «frisk $i$ ånden, men syk på legemet og i sin omsorg for datteren

ofrer Ingeborg til nonneklosteret i Oslo» (7, s. 98). Kanskje kunne et av «våre» barn ha vært en «Ingeborg»?

Skjelettfunn bidrar kun i begrenset grad til vår kunnskap om middelalderens sykdommer. Men mange skriftlige beretninger kaster et indirekte lys over tiden. Sykdom ble antatt å skyldes overnaturlige makter. Dødeligheten var svært høy, infeksjonssykdommene vendte regelmessig tilbake. Det vi nå kjenner som barnesykdommer, var livstruende (8). Klostervesenet ga barmhjertighet til syke og fattige. «Våre» to barn fikk bare et kort liv, men forhåpentligvis likevel et godt liv, skjermet i Nonneseter kloster.

\section{Jacob M. Klafstad (f. 1934)}

er pensjonert spesialist i maxillofacial kirurgi. Forfatter har fylt ut ICMJE-skjemaet og oppgir ingen interessekonflikter.

\section{Litteratur}

1. Gjerland L. Et lite stykke Oslo. Oslo: Dreyer, 2012.

2. Fischer G. Oslo under Eikaberg. Oslo: Aschehoug. 1950

3. Klafstad J. Odontopathology of a Norwegian medieval population. Ossa: International journal of skeletal research 1978; 5: 43-55.

4. Klafstad J. Middelaldertannrot på avveie. Tidsskr Nor Legeforen 2010; 130: 2472.

5. Dahlberg GN. A fostre, eller ikke å fostre»: fostringsinstitusjoner i Europa før og etter kristningen. Oslo: Universitetet i Oslo, 2002. www.duo.uio.no/handle/10852/26664 (26.4.2013).

6. Møller-Christensen V. Bogen om Æbelholt kloster København: Dansk Videnskabs Forlag, 1958.

7. Schia E. Oslo innerst i Viken. Oslo: Aschehoug, 1991

8. Klafstad J. Oslohelsen i middelalderen. St. Hallvard 2000; nr. 4: 26-36.

Mottatt 30.1. 2013, første revisjon innsendt 31.3. 2013, godkjent 26.4. 2013. Medisinsk redaktør Are Brean. 